Article

\title{
Interactive Effects of Nitrogen and Potassium Fertilizers on Quantitative-Qualitative Traits and Drought Tolerance Indices of Rainfed Wheat Cultivar
}

\author{
Mohammad Hossein Sedri ${ }^{1, *}$, Ebrahim Roohi ${ }^{2} \mathbb{D}$, Mohsen Niazian ${ }^{2} \mathbb{D}$ and Gniewko Niedbała ${ }^{3} \mathbb{C}$ \\ 1 Soil and Water Research Department, Kurdistan Agricultural and Natural Resources Research and Education \\ Center, Agricultural Research, Education and Extension Organization (AREEO), Sanandaj 6616936311, Iran \\ 2 Crop and Horticultural Science Research Department, Kurdistan Agricultural and Natural Resources \\ Research and Education Center, Agricultural Research, Education and Extension Organization (AREEO), \\ Sanandaj 6616936311, Iran; roohiebrahim@yahoo.com (E.R.); mniazian@ut.ac.ir (M.N.) \\ 3 Department of Biosystems Engineering, Faculty of Environmental and Mechanical Engineering, \\ Poznań University of Life Sciences, Wojska Polskiego 50, 60-627 Poznan, Poland; \\ gniewko.niedbala@up.poznan.pl \\ * Correspondence: sedri_mh@yahoo.com; Tel.: +98-9181732273
}

check for

updates

Citation: Sedri, M.H.; Roohi, E.;

Niazian, M.; Niedbała, G. Interactive Effects of Nitrogen and Potassium Fertilizers on QuantitativeQualitative Traits and Drought Tolerance Indices of Rainfed Wheat Cultivar. Agronomy 2022, 12, 30. https://doi.org/10.3390/ agronomy 12010030

Academic Editor: Aliasghar Montazar

Received: 24 November 2021 Accepted: 22 December 2021 Published: 24 December 2021

Publisher's Note: MDPI stays neutral with regard to jurisdictional claims in published maps and institutional affiliations.

Copyright: (C) 2021 by the authors. Licensee MDPI, Basel, Switzerland. This article is an open access article distributed under the terms and conditions of the Creative Commons Attribution (CC BY) license (https:// creativecommons.org/licenses/by/ $4.0 /)$.

\begin{abstract}
Increasing global food requirements and global warming are two challenges of future food security. Water availability and nutrient management are two important factors that affect high-yield and high-quality wheat production. The main and interactive effects of nitrogen and potassium fertilizers on quantitative-qualitative properties and drought tolerance of an Iranian rainfed cultivar of wheat, Azar-2, were evaluated. Four rates of nitrogen (N0, N30, N60, and N90 kg/ha), along with four concentrations of potassium (K0, K30, K60, and $\mathrm{K} 90 \mathrm{~kg} / \mathrm{ha}$ ), were applied in rainfed (drought stress) and non-stress conditions. The interactive effect of $\mathrm{N} \times \mathrm{K}$ was significant on nitrogen and protein contents of grains at $5 \%$ and $1 \%$ probability levels, respectively. Different trends of SSI, STI, K1STI, and K2STI indexes were observed with the interactive levels of nitrogen and potassium. The lowest SSI index (0.67) was observed in N30K30, whereas the highest STI (1.07), K1STI (1.46), and K2STI (1.51) indexes were obtained by N90K60 and N90K90. The obtained results could be useful to increase yield and quality of winter rainfed wheat cultivars under drought stress with cool-rainfed areas. N60K30 and N90K60 can be recommended to increase the grain yield and protein content of rainfed wheat under drought stress and non-stress conditions, respectively.
\end{abstract}

Keywords: drought stress; protein content; rainfed; yield stability; wheat

\section{Introduction}

Increasing the grain yield and quality of wheat (Triticum aestivum L.), as the most widely distributed cereal crop and major staple food crop in the world, is crucial to meet the growing demands of increasing human population [1,2]. Drought stress is a very important abiotic stress that constricts wheat production, especially in arid and semiarid regions of the world, such as Iran [3]. Significant decreased nest photosynthesis, stomatal conductance, relative water contents, 100-grain weight, and grain yield have been reported for 14 bread wheat genotypes under drought stress [4]. Low amounts of mineral nutrients in the soil is the second important constraint for wheat production in arid and semi-arid regions [5]. For an increasing human population, ever increasing global food requirements, and global warming, the development of basic and applied research on drought stress - as one of the most important treats of world food security-is very important [6-8]. Finding plant genotypes with high yield under drought stress and/or enhancing tolerance of drought sensitive genotypes are the proficient approaches to deal with drought stress-induced losses [9]. Selection and breeding of plants are the most economic and effective ways to overcome abiotic stresses [10]. Direct selection of drought 
tolerance is not effective, as it is a quantitative character with low heritability. Drought tolerance indices (DTI), such as tolerance (TOL) [11], mean productivity (MP) [11], stress susceptibility index (SSI) [12], geometric mean productivity (GMP) [13], harmonic mean (HARM) [14], relative drought index (RDI) [15], stress tolerance index (STI) [13], yield index (YI) [16], and yield stability index (YSI) [17], which provide a measure of drought based on yield loss under drought condition in comparison to normal condition, are useful tools to assess the tolerance of different genotypes to stressful conditions [18]. Yield-based DTI have been widely applied by researchers to assess the drought tolerance of various important crops, such as oilseed rape (Brassica napus L.) [19], teff (Eragrostis tef (Zucc.) Trotter) [20], upland cotton (G. hirsutum L.) [21], and wheat [3,9,22-24].

As aforementioned, enhancing tolerance of drought sensitive genotypes is the second breeding strategy to cope with detrimental outcomes of drought stress. There are some adjuvants that their exogenous supply can increase the plant's ability to protect itself under stressful conditions [25]. The exogenous supply of some nutrient elements can reduce the inhibitory effects of drought stress on different plants. Nitrogen $(\mathrm{N})$, phosphorous $(\mathrm{P})$, and potassium $(\mathrm{K})$ are three important plant stress ameliorants [26]. Creation of favorable growing conditions buffers plant stress, and long-term grain yield stability of winter wheat can be obtained through balanced nutrient supply [27]. Nitrogen (N)_as vital structural component of proteins, Rubisco, nucleic acids, chlorophyll system, and some hormones [28]-is an important nutrient that has a significant role in stimulating plant growth, development, and increasing crop productivity under environmental stresses [26]. In addition to drought stress, nitrogen deficiency is one of the primary factors limiting productivity of wheat [29]. Agami et al. [30] investigated the effect of exogenous nitrogen supply, $\mathrm{N}$-fertilizer ( 0.3 and $0.6 \mathrm{~g} \mathrm{~N} / \mathrm{kg}$ soil), on drought tolerance of wheat plants and reported that under deficit irrigation condition (60\% of ETc), nitrogen-treated plants had higher growth and yield characteristics compared to the untreated plants. They also reported that nitrogen-treated plants were significantly better than untreated plants in terms of grain yield, photosynthetic pigments, and antioxidant enzymes activities. Applied $\mathrm{N}$-fertilizer alleviated the adverse effects of drought stress in wheat plants through keeping higher relative water content and water use efficiency, higher osmoprotectants (soluble carbohydrates, soluble proteins, total soluble phenols, and free proline) and antioxidant systems (peroxidase, superoxide dismutase, glutathione reductase, and catalase) [30]. Sedri et al. [3] assessed the effect of different concentrations of nitrogen fertilizer $(0,30$, 60,90 , and $120 \mathrm{~kg} / \mathrm{ha}$ ) on DTI of mean productivity (MP), GMP, TOL, SSI, STI, and modified stress tolerance index (MSTI), in a rainfed wheat cultivar and reported that drought tolerance of nitrogen-treated plants was significantly more than control plants, and STI was the best index for drought tolerance assessment. Potassium is another important nutrient element involved in grain weight, yield, and drought resistance of cereals [31,32]. The significantly higher content of endogenous $\mathrm{K}$ in a drought-resistant variety than a drought-sensitive variety of wheat has been reported previously [33]. Potassium is also involved in biotic stress tolerance of wheat [34]. Therefore, it seems that exogenous supply of this nutrient element can lead to positive results in wheat under water deficiency conditions. The positive effects of $\mathrm{K}$ fertilizer on grain filling and drought resistance of wheat have been reported $[35,36]$. Potassium $\left(\mathrm{K}^{+}\right)$has significant effects on enzyme activation, protein synthesis, photosynthesis, stomatal movement, and water-relation (turgor regulation and osmotic adjustment) in plants [37]. The co-application of $\mathrm{N}$ and $\mathrm{K}$ can prevent the harmful effects of drought stress through different routes. Application of potassium-nitrate-containing chitosan/montmorillonite microparticles led to significant increased root and shoot length, shoot fresh and dry weight, chlorophyll a, carotenoids, total soluble proteins, soluble sugars, potassium, and phosphorous concentrations of spinach (Spinacia oleracea L.) under severe drought stress [5].

In addition to the crop yield, there is an increasing attention to grain quality, especially the grain protein content, in modern intensive agricultural production [38]. In arid and semi-arid environments, wheat grain quality could be greatly affected by drought stress [39]. 
One of the major challenges in producing high-quality wheat is inconsistency and instability of wheat grain quality during grain filling [40]. Drought stress has an adverse effect on wheat grain development through affecting booting and anthesis stages, disrupting meiosis, reducing pollination efficiency, aborting ovules and seeds, reducing days to anthesis and maturity, and resulting in early seed maturity [41].

Decreased grain yield and quality are the most important challenges of wheat production under drought stress in arid and semi-arid regions. In addition to alleviating the adverse effects of drought stress, the co-application of nitrogen with phosphorus, potassium, and sulfur nutrients can reduce the rates of $\mathrm{N}$ fertilizer required by wheat, improve grain yield and protein content, grain yield and grain protein content stability, and subsequently reduce environmental pollution [42]. The present study was conducted to investigate the main and interactive effects of nitrogen and potassium fertilizers on yield components, qualitative characteristics, and yield-based DTI of an Iranian rainfed cultivar (Azar-2) of wheat and find the best interacting levels of $\mathrm{N}$ and $\mathrm{K}$ on mentioned characteristics under non-stress and drought stress conditions. We hypothesized that yield components, qualitative characteristics, and DTI of Azar-2 would all be affected by the interactions of $\mathrm{N}$ and $\mathrm{K}$ fertilizers.

\section{Materials and Methods}

\subsection{Experimental Design and Treatments}

Two field experiments were conducted, under rainfed (drought stress) and supplemental irrigation (non-stress) conditions, to assess the main and interactive effects of different concentrations of $\mathrm{N} \times \mathrm{K}$ fertilizers on quantitative-qualitative properties, and drought tolerance of Azar-2 rainfed cultivar of wheat, in two continuous growing seasons (2014-2015 and 2015-2016). The treatments consisted of four rates of $\mathrm{N}$ (N0, N30, N60, and N90 kg/ha) and $\mathrm{K}(\mathrm{K} 0, \mathrm{~K} 30, \mathrm{~K} 60$, and $\mathrm{K} 90 \mathrm{~kg} / \mathrm{ha})$ fertilizers. Factorial experiments, based on randomized complete block design (RCBD), were conducted in Arid Land Agricultural Research Station of Qamloo in Kurdistan province, Iran $\left(47^{\circ} 29^{\prime}\right.$ E longitudes and $35^{\circ} 9^{\prime} \mathrm{N}$ latitude). The climate of this region is dry and cool [3].

For soil test, soil samples (6 samples, each being a combination of 10 samples) were taken from 0-30 cm depth, before planting. The physic-chemical soil analysis of experimental sites is presented in Table 1 . Urea $(46 \% \mathrm{~N})$ and potassium chloride $\left(60 \% \mathrm{~K}_{2} \mathrm{O}\right)$ fertilizers were used as the source of $\mathrm{N}$ and $\mathrm{K}$ nutrients, respectively. Half of the mentioned concentrations of $\mathrm{N}$ and $\mathrm{K}$ fertilizers were broadcasted uniformly in experimental plots; before cultivation in fall, and remaining half was broadcasted in plots at tillering stage of wheat in spring as top-dress fertilizer. Azar-2 rainfed cultivar of wheat was sown at $150 \mathrm{~kg}$ seed per ha in plots of size $4 \mathrm{~m} \times 5 \mathrm{~m}$.

Table 1. Soil chemical and physical properties at arid land agricultural research station of Qamloo.

\begin{tabular}{|c|c|c|c|c|c|c|c|c|c|}
\hline Environment & $\begin{array}{l}\text { SP } \\
(\%)\end{array}$ & $\begin{array}{c}\mathrm{Ec} \times 10^{-3} \\
(\mathrm{ds} / \mathrm{m})\end{array}$ & $\mathrm{pH}$ & $\begin{array}{c}\text { T.N.V } \\
(\%)\end{array}$ & $\begin{array}{l}\text { OC } \\
(\%)\end{array}$ & $\begin{array}{c}\text { Total.N } \\
\text { (\%) }\end{array}$ & $\begin{array}{c}\text { P.ava } \\
\text { (mg/kg) }\end{array}$ & $\begin{array}{c}\text { K.ava } \\
\text { (mg/kg) }\end{array}$ & Texture \\
\hline \multirow{3}{*}{$\begin{array}{l}\text { Drought } \\
\text { stress }\end{array}$} & 37.820 & 0.590 & 7.900 & 14.380 & 0.700 & 0.080 & 15.900 & 210.000 & Clay \\
\hline & 37.930 & 0.570 & 7.900 & 25.140 & 0.650 & 0.080 & 16.700 & 200.000 & Clay \\
\hline & 39.760 & 0.620 & 7.950 & 15.000 & 0.670 & 0.070 & 16.400 & 180.000 & Clay \\
\hline \multirow{3}{*}{$\begin{array}{l}\text { Non- } \\
\text { stress }\end{array}$} & 39.190 & 0.600 & 7.900 & 15.250 & 0.670 & 0.080 & 16.100 & 160.000 & Clay \\
\hline & 38.320 & 0.580 & 7.900 & 14.880 & 0.680 & 0.070 & 14.700 & 170.000 & Clay \\
\hline & 39.080 & 0.590 & 7.900 & 15.250 & 0.690 & 0.080 & 14.700 & 160.000 & Clay \\
\hline
\end{tabular}

In non-stress conditions, supplemental irrigations were conducted in flowering and grain filling developmental steps. The volumetric soil water contents at depth 0-30 cm (rooting zone) and 30-60 cm were calculated using a time domain reflectometry (TDR) 
probe in different phonological stages. The net depth of irrigation $(\mathrm{mm})$ to bring the soil to field capacity was calculated using Equation (1) [43].

$$
I_{n}=\left(\theta_{F C}-\theta_{i}\right) \times D_{z}
$$

where, $I_{n}$ is the net depth of irrigation $(\mathrm{mm})$, is the volumetric soil water content at field capacity $\left(\mathrm{cm}^{3} / \mathrm{cm}^{-3}\right)$, is the volumetric soil water content before irrigation $\left(\mathrm{cm}^{3} / \mathrm{cm}^{-3}\right)$, and $D_{z}$ is the rooting depth $(\mathrm{mm})$.

\subsection{Measurements}

The main and interactive effects of $\mathrm{N}$ and $\mathrm{K}$ fertilizers were assessed on quantitative (grain yield, straw yield, and 1000-seed weight) and qualitative (nitrogen and potassium concentrations in flag leaves, nitrogen, potassium, and protein content of seeds) characteristics of Azar-2 cultivar under both drought stress and non-stress conditions. Flag leaf samples were gathered at the heading stage to measure their nitrogen and potassium concentrations. Kjeldahl method was applied to determine the nitrogen content in flag leaf and combined seed samples. Protein content (\%) of seed samples was determined by multiplying $\mathrm{N}$ content by 6.25 [25]. Atomic absorption spectrum using a flame photometer was applied to estimate the potassium concentration of flag leaf and combined seed samples according to Yoshida et al. [44].

Grain yield, straw yield, and 1000-seed weight (TSW) were measured from randomly selected samples at harvest stage.

\subsection{Grain Yield and Grain Protein Content Stability}

Stability of grain yield and protein content under interactive effects of applied $\mathrm{N}$ and $\mathrm{K}$ fertilizers was evaluated using coefficient of variation (CV) index (Equation (2)) [45].

$$
\text { Coefficient of variance }(C V)=(\sigma / \bar{\Upsilon}) \times 100
$$

where, $\mathrm{CV}$ is the coefficient of variance, $\sigma$ is the standard deviation (t/ha), and $\bar{\Upsilon}$ is the average crop yield ( $\mathrm{t} / \mathrm{ha})$.

\subsection{Drought Tolerance Assessment}

To assess the interactive effects of applied $\mathrm{N}$ and $\mathrm{K}$ fertilizers on drought tolerance of Azar-2 cultivar of wheat, different yield-based DTI-including MP, GMP, TOL, SSI, STI, and modified stress tolerance index (MSTI) — were calculated. Potential yield in normal (the obtained seed yield in non-stress condition) $(Y p)$ and drought stress condition $\left(Y_{s}\right)$, the average performance in non-stress condition $\left(\bar{Y}_{p}\right)$, and drought stress condition $\left(\bar{Y}_{s}\right)$, were measured and then the mentioned DTI were calculated according to the following Equations (3)-(7) [11-13].

$$
\begin{gathered}
M p=\frac{Y p+Y_{s}}{2} \\
G M P=\sqrt{Y p \times Y_{s}} \\
T O L=Y p-Y_{s} \\
S S I=\frac{1-\left(Y_{s} / Y_{p}\right)}{1-\left(\overline{Y_{s}} / \overline{Y p}\right)} \\
S T I=\frac{Y_{s} \times Y_{p}}{\overline{Y_{p}^{2}}}
\end{gathered}
$$

Modified stress tolerance index were calculated for non-stress (defined as K1STI), and drought stress (defined as K2STI) conditions, according to Equations (8) and (9) [46], respectively

$$
\mathrm{K} 1=\mathrm{Y} 2 \mathrm{p} / \tilde{\mathrm{y}}^{2} \mathrm{P}
$$




$$
\mathrm{K} 2=\mathrm{Y} 2 \mathrm{~s} / \tilde{\mathrm{y}}^{2} \mathrm{~s}
$$

\subsection{Statistical Analysis}

Statistical analyses, including the analysis of variance (ANOVA) and means comparison analysis were carried out using the MSTATC software. Least significant difference (LSD) test at $1 \%(p \leq 0.01)$ and $5 \%(p \leq 0.05)$ probability levels was used for means comparison analysis. The coefficient of variance and drought tolerance indices were calculated using Excel 2010 software. Simple correlation analysis was conducted using SAS ${ }^{\circledR}$ software (SAS Institute Inc., Cary, NC, USA).

\section{Results and Discussions}

3.1. Effect of the Mineral Content of the Soil on Morphological and Qualitative Parameters of the Azar-2 Wheat Cultivar

The correlation coefficient analysis of measured mineral contents of field soil with quantitative and qualitative characteristics of Azar-2 wheat cultivar showed that soil minerals such as $\mathrm{N}, \mathrm{P}$, and $\mathrm{K}$ had significant correlation with grain yield and grain protein content of Azar-2 cultivar in both stress and non-stress condition (Table 2). As the present study was conducted in an open field, the obtained results are valuable for the future field experiments to predict the grain yield and quality of the cultivated crop.

Table 2. Correlation coefficients of basic mineral content of the field soil with the quantitative and qualitative parameters of the Azar-2 wheat cultivar.

\begin{tabular}{ccccc}
\hline \multirow{2}{*}{ Plant Characteristics } & \multicolumn{3}{c}{ Soil Mineral Contents } \\
\cline { 2 - 5 } & Total.N (\%) & P.ava $(\mathbf{m g} / \mathbf{k g})$ & K.ava $(\mathbf{m g} / \mathbf{k g})$ & Total Neutralizing Value (T.N.V) \\
\hline Grain yield & $0.745^{* *}$ & $0.591^{* *}$ & $0.432^{*}$ & $0.081 \mathrm{~ns}$ \\
Straw yield & $0.230^{*} \mathrm{~ns}$ & $0.415^{*}$ & $0.123 \mathrm{~ns}$ & $0.341 \mathrm{~ns}$ \\
1000-seed weight & $0.653^{* *}$ & $0.471^{*}$ & $0.215 \mathrm{~ns}$ & $0.182 \mathrm{~ns}$ \\
Grain N content & $0.823^{* *}$ & $0.302 \mathrm{~ns}$ & $0.243 \mathrm{~ns}$ & $0.124 \mathrm{~ns}$ \\
Grain K content & $0.146 \mathrm{~ns}$ & $0.214 \mathrm{~ns}$ & $0.732^{* *}$ & $0.632^{* *}$ \\
Grain protein content & $0.516^{* *}$ & $0.504^{* *}$ & $0.361 \mathrm{~ns}$ & \\
\hline
\end{tabular}

$* * * *$ Significant at $1 \%$ and $5 \%$ probability level, respectively. ns: Not significant.

3.2. Main and Interactive Effects of $N$ and K Fertilizers on Quantitative Properties of Wheat under Non-Stress and Drought Stress Conditions

The results of combined ANOVA showed that, under drought stress condition, the main effect of year was significant on grain yield and straw yield at $1 \%$ probability level; however, it was not affected 1000-seed weight trait (Table 3). Under non-stress condition, the main effect of year was significant on grain yield, straw yield, and 1000-seed weight of Azar-2 cultivar of wheat at 1\% probability level (Table 3). Assessing yield trends in wheat dryland farming and under different fertilization conditions is important to recommend the best fertilizer rates and keep yield increases [47]. Crop yield stability can be assessed through the CV, sustainable yield index (SYI), and some statistical methods such as additive main effects and multiplicative interactions (AMMI). Obtained CV percentage of grain yield under drought stress condition (15.59) was more than that of non-stress condition (10.75) (Table 3). These results indicate higher variation degree and lower stability of average grain yield of Azar-2 cultivar of wheat during 2014-2015 and 2015-2016 growing seasons under drought stress conditions. Unlike grain yield, the CV percentage of straw yield under drought stress conditions (22.6) was lower than calculated CV under non-stress condition (23.25) (Table 3). It is obvious that environmental factors, such as water availability and nutrients, can affect both crops yield and yield stability. In regions with variable waterdeficit years, additional water inputs led to more stable yield productivity in different crops, such as wheat, maize, rice, and soybean, with [48]. Balanced nutrient supply can also support long-term crop yield stability [27]. 
Table 3. Combined analysis of variance of the main and interactive effects of nitrogen and potassium fertilizers on quantitative characteristics of Azar-2 cultivar of wheat under drought stress and nonstress environments.

\begin{tabular}{|c|c|c|c|c|c|c|c|}
\hline \multirow{3}{*}{ Source of Variation } & \multirow{3}{*}{$\mathrm{df}^{\mathrm{a}}$} & \multicolumn{6}{|c|}{ Mean Squares } \\
\hline & & \multicolumn{3}{|c|}{ Drought Stress } & \multicolumn{3}{|c|}{ Non-Stress } \\
\hline & & Grain Yield & Straw Yield & 1000-Seed Weight & Grain Yield & Straw Yield & 1000-Seed Weight \\
\hline Year $(\mathrm{Y})$ & 1 & $25,043,094.000 * *$ & $463,457,153.760 * *$ & $0.076 \mathrm{~ns}$ & $6,043,077.042 * *$ & $306,159,695.010$ ** & $283.800 * *$ \\
\hline Year $\times$ Block & 4 & $235,071.146$ * & $753,715.948 \mathrm{~ns}$ & $11.898^{*}$ & $1,941,093.104$ ** & $4,435,583.292 * *$ & $25.351 * *$ \\
\hline Nitrogen (N) & 3 & $1,570,010.069 * *$ & $186,390.955 \mathrm{~ns}$ & $63.570^{* * *}$ & $4,827,021.917$ ** & $945,981.038 \mathrm{~ns}$ & $14.306 *$ \\
\hline $\mathrm{Y} \times \mathrm{N}$ & 3 & $171,841.917 \mathrm{~ns}$ & $328267.622 \mathrm{~ns}$ & $4.778 \mathrm{~ns}$ & $642,481.125$ ** & $503,941.872 \mathrm{~ns}$ & $4.887 \mathrm{~ns}$ \\
\hline Potassium (K) & 3 & $20,432.819 \mathrm{~ns}$ & $547,642.955 \mathrm{~ns}$ & $2.226 \mathrm{~ns}$ & 5886.944 ns & $1,035,804.233 \mathrm{~ns}$ & $17.604 \mathrm{~ns}$ \\
\hline $\mathrm{Y} \times \mathrm{K}$ & 3 & $143,145.944 \mathrm{~ns}$ & $1,253,567.399 \mathrm{~ns}$ & $5.846 \mathrm{~ns}$ & $31,186.819 \mathrm{~ns}$ & $2,319,904.622 \mathrm{~ns}$ & $0.608 \mathrm{~ns}$ \\
\hline $\mathrm{N} \times \mathrm{K}$ & 9 & $79,243.440 \mathrm{~ns}$ & $163,752.890 \mathrm{~ns}$ & $5.099 \mathrm{~ns}$ & $55,293.694 \mathrm{~ns}$ & $1,114,630.612 \mathrm{~ns}$ & $5.808 \mathrm{~ns}$ \\
\hline $\mathrm{Y} \times \mathrm{N} \times \mathrm{K}$ & 9 & $111,048.639 \mathrm{~ns}$ & $808,701.927 \mathrm{~ns}$ & $1.765 \mathrm{~ns}$ & $125,138.421 \mathrm{~ns}$ & $2,078,221.446 \mathrm{~ns}$ & $5.968 \mathrm{~ns}$ \\
\hline Error & 60 & $80,213.690$ & $1,003,141.292$ & 4.206 & $66,966.582$ & $1,063,045.258$ & 4.356 \\
\hline $\mathrm{CV}(\%)$ & & 15.590 & 22.600 & 5.170 & 10.750 & 23.250 & 4.380 \\
\hline
\end{tabular}

a degree of freedom; ${ }^{* *},{ }^{*}$ : Significant at $1 \%$ and $5 \%$ probability level, respectively. ns: Not significant.

The trend of wheat grain yield stability, based on calculated CV (\%), with interactive effects of different rates of $\mathrm{N}$ and $\mathrm{K}$ fertilizers is depicted in Figure 1a. The highest and lowest CV percentages were obtained from N0 × K30 (30.14\%) and N90 × K60 (18.17\%) (Figure 1a). These results indicate positive effect of combined use of $\mathrm{N}$ and $\mathrm{K}$ fertilizers on grain yield stability of rainfed Azar-2 wheat. Azar-2 is a well-known dryland wheat cultivar in Iran, with acceptable levels of water use efficiency, grain yield, and biomass production under water-limited conditions [49]. At present, Azar-2 has the second rank of cultivated area in dryland conditions of cold and temperate regions of Iran. This cultivar can be useful for cultivation in arid and semi-arid regions of the world. The present study conducted in two constitute years to assess the drought response of this cultivar under the effect of $\mathrm{N}$ and $\mathrm{K}$ fertilizers. Azar-2 cultivar in rotation with a plant species that enriches the soil with nitrogen, such as chickpea (Cicer arietinum), is ideal for rainfed agriculture in countries with water scarcity. This rotation can improve nitrogen uptake, grain protein, soil nitrogen, soil properties, and elevated availability of nutrients [50]. Liu et al. [51] investigated the effects of different rates of $\mathrm{N}$ fertilizer $(100 \%, 75 \%, 50 \%, 25 \%$, and $0 \%$ ) and two tillage patterns (conventional tillage and no-tillage) on wheat and maize productivity in a long-term experiment (10-year). Authors concluded that higher yield stability, according to the calculated SYI, in both wheat and maize cropping system were obtained by application of 75\% and 50\% N [51]. In terms of yield stability, the combined use of different fertilizers can be more effective than application of one kind of fertilizer alone [52]. In rainfed winter wheat, using a long-term fertilization experiment (20-year), it was revealed that higher grain yield and sustaining the productivity were obtained by integrated use of $\mathrm{N}$ and phosphor (P) fertilizers than the sole application of $\mathrm{N}$ and/or $\mathrm{P}$ [47]. Han et al. [45] assessed the effects of inorganic fertilizers (N, NP, NPK) and organic manure (M) on the yield stability of rice and wheat during a long term (34-year) field experiment and reported that the combined use of both organic manure and inorganic fertilizer led to lower $\mathrm{CV}$ of wheat yield and straw biomass. The yield stability analysis of winter wheat in a long-term fertilization experiment (36-year), using AMMI method, it was revealed that $62.3 \%, 26.3 \%$, and $11.4 \%$ of sums of squares were attributable to fertilization effect, environmental effect, and fertilization $\times$ environmental interaction effect, respectively. In addition, authors concluded that the combination of organic and inorganic fertilization led to more stable yields than applied organic or inorganic fertilization alone [53].

In both drought stress and non-stress conditions, the main effect of $\mathrm{N}$ fertilizer on grain yield was significant at $1 \%$ probability level (Table 3 ). The main effect of $\mathrm{N}$ fertilizer on $1000-$ seed weight trait was significant under both drought stress and non-stress conditions, at $1 \%$ and $5 \%$ probability levels, respectively (Table 3 ). However, this effect was not significant on straw yield under non-stress and drought stress environments (Table 3). Results of means comparison analysis using LSD test showed that grain yield of Azar-2 cultivar of wheat was increased with increasing levels of $\mathrm{N}$ fertilizer, under both drought stress and 
non-stress environments. However, obtained grain yields in the non-stress environment were more than those obtained under drought stress conditions (Table 4).
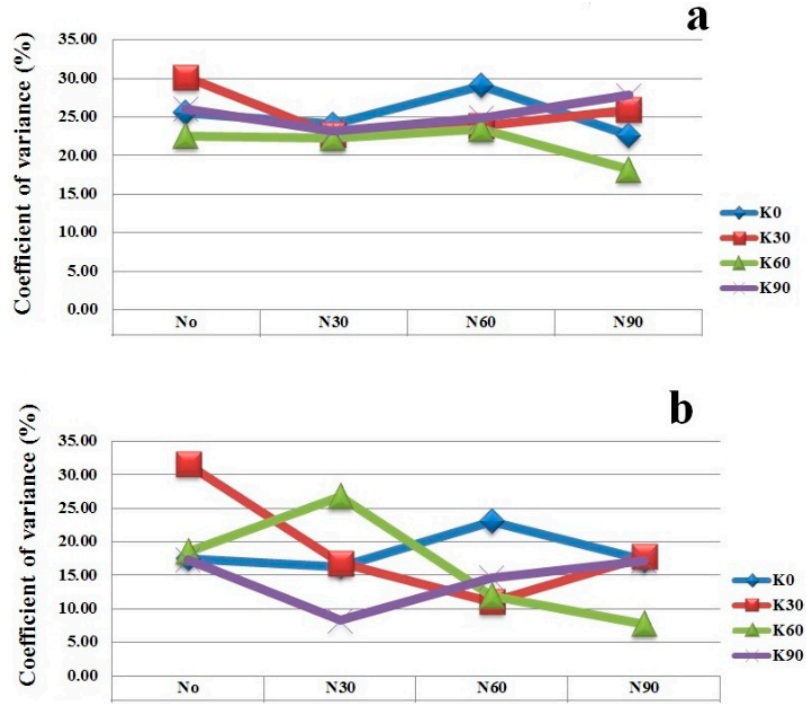

Figure 1. Grain yield and grain protein content stability of rainfed Azar-2 cultivar of wheat. (a) Trend of grain yield stability of wheat Azar-2 cultivar under interaction effects of different rates of nitrogen and potassium fertilizers. (b) Trend of grain protein content stability of wheat Azar-2 cultivar under interaction effects of different rates of nitrogen and potassium fertilizers.

Table 4. Means comparison analysis of the main effect of applied concentrations of nitrogen fertilizer on quantitative characteristics of Azar-2 cultivar of wheat under drought stress and non-stress environments.

\begin{tabular}{ccccc}
\hline \multirow{2}{*}{ Nitrogen (kg/ha) } & \multicolumn{2}{c}{ Drought Stress } & \multicolumn{2}{c}{ Non-Stress } \\
\cline { 2 - 5 } & Grain Yield (kg/ha) & 1000-Seed Weight (g) & Grain Yield (kg/ha) & 1000-Seed Weight (g) \\
\hline N0 & 1473.000 & 41.580 & 1893.000 & 48.820 \\
N30 & 1788.000 & 40.320 & 2279.000 & 47.500 \\
N60 & 1941.000 & 39.000 & 2657.000 & 27.250 \\
N90 & 2066.000 & 37.820 & 2857.000 & 47.160 \\
LSD (5\%) & 163.500 & 1.184 & 149.400 & 1.205 \\
LSD (5\%) & 217.500 & 1.575 & 198.700 & 1.603 \\
\hline
\end{tabular}

Zhang et al. [54] assessed the effect of irrigation and nitrogen application on grain yield and quality of winter wheat over three cropping seasons and reported that $\mathrm{N}$ fertilizer significantly increased grain yield, grain protein and the total, essential, and non-essential amino acid content. The results of a long-term (20-years) evaluation of effects of $\mathrm{N}$ fertilizer on durum wheat revealed that grain yield was remarkably increased by $\mathrm{N}$ fertilizer application [55]. It has been reported that the effect of nitrogen fertilization on grain yield variation of winter wheat is more important than annual weather conditions [27]. Nitrogen affects canopy formation, photosynthesis, and subsequently wheat grain yield. Although growth, grain yield, and quality of wheat absolutely depend upon substantial $\mathrm{N}$ inputs [56], finding the optimum concentration and avoid over and under-use of $\mathrm{N}$ fertilizer is very important to keep maximum productivity with reduced costs, resource waste, and environmental pollution [51].

The interaction effect of $\mathrm{N} \times \mathrm{K}$ was not significant on grain yield, straw yield, and 1000-seed weight of wheat under both drought stress and non-stress environments (Table 3). These results may relate to the $\mathrm{K}$ deficiency in the soil of experimental site (Table 1$)$. In soils with high concentrations of $\mathrm{P}, \mathrm{K}$, and $\mathrm{S}$, less $\mathrm{N}$ fertilizer might be required for crops to reach rainfall-limited yield potentials. In addition, genetic variation and weather conditions can 
also affect $\mathrm{N} \times$ nutrient(s) interactions [42]. In addition, water deficiency and drought stress may prevent the absorption of potassium in wheat plants. In comparison with control treatment (N0K0), grain yield of Azar-2 cultivar of wheat increased by $52 \%$ with application of N90K60 (Figure 2a). The highest positive increases were then obtained by N90K90 (46\%) and N90K0 (42\%) interactive effects, respectively (Figure 2a).
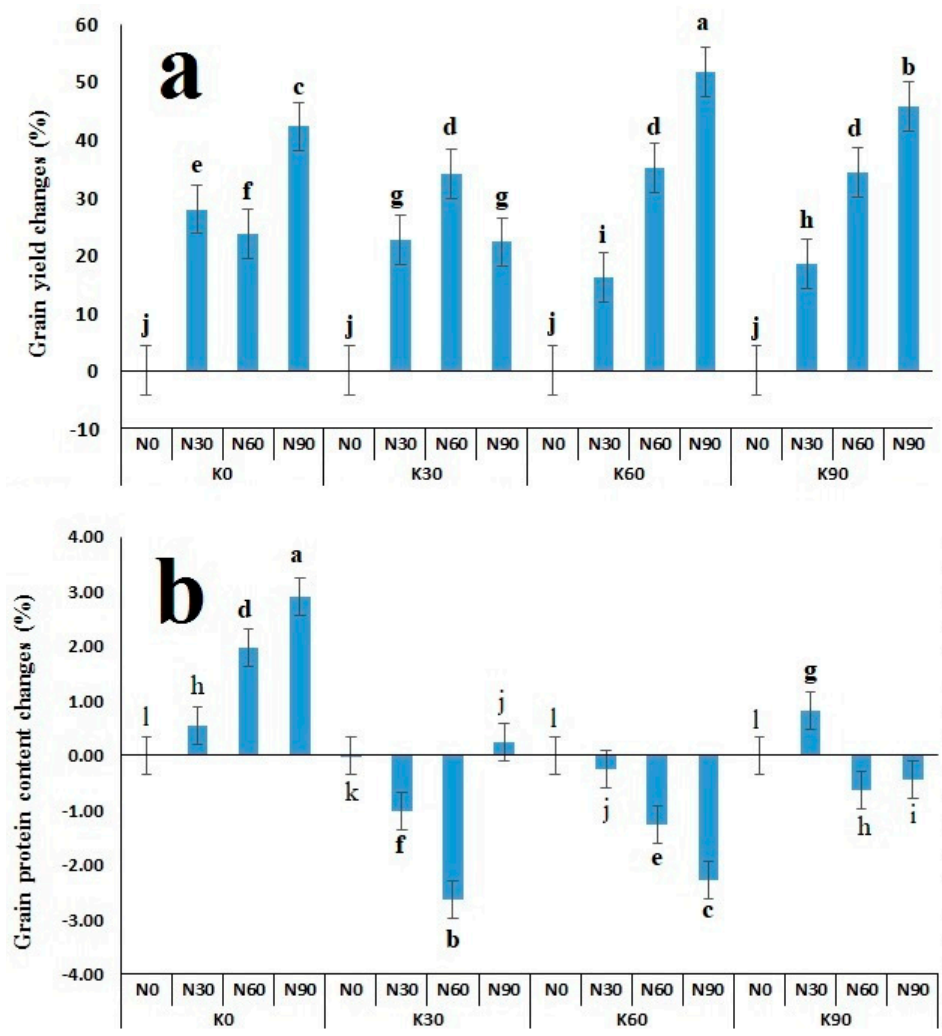

Figure 2. Changes of grain yield and protein content of wheat Azar-2 cultivar under applied interactive rates of $\mathrm{N}$ and $\mathrm{K}$ fertilizers versus control treatment. (a) Differences of grain yield achieved by interactive effects of $\mathrm{N}$ and $\mathrm{K}$ fertilizers versus control treatment. (b) Differences of grain protein content achieved by interactive effects of $\mathrm{N}$ and $\mathrm{K}$ fertilizers versus control treatment. Means followed by the same letters within columns are not significantly different at the $5 \%$ level.

Based on the results of combined ANOVA, the main effect of $\mathrm{K}$ fertilizer, its interactive effects with year (year $\times$ potassium) and with $\mathrm{N}$ fertilizer (nitrogen $\times$ potassium), were not significant on all investigated quantitative characteristics of Azar-2 cultivar of wheat neither in drought stress nor in non-stress environments (Table 3). In addition, the interactive effect of year $\times$ nitrogen $\times$ potassium was not significant on grain yield, straw yield, and 1000-seed weight traits, under both drought stress and non-stress conditions (Table 3 ). It can be related to the non-significant main effect of potassium. In the hierarchy of nutrients for wheat, carbon, $\mathrm{N}$ and $\mathrm{P}$ are more important than $\mathrm{K}$ [57]. Although it has been reported that $\mathrm{K}$ fertilizer can affect grain filling and grain yield of wheat under drought stress conditions [32]; however, the main effect of $\mathrm{K}$ and its interactive effect with $\mathrm{N}$ fertilizer were not significant on grain yield and 1000-seed yield of wheat in the present study. It can be related to the cool condition of the present study, as the previous study was conducted in a controlled dry condition [32]. Assessing the interactive effects of $\mathrm{N}$ fertilizer with other components involved in tolerance to cold and chilling stresses, such as brassinosteroids [58], could be more helpful to increase both drought-cold tolerance in wheat under the environments similar to the present study. 
3.3. Main and Interactive Effects of $N$ and $K$ Nutrients on Qualitative Properties of Wheat under Non-Stress and Drought Stress Conditions

According to the results of combined ANOVA, potassium concentration of flag leaves and nitrogen and protein contents of grains were changed during to evaluated growing seasons, under drought stress condition (Table 5). Vazquez et al. [59] also reported the significant effect of the year on grain yield and grain protein concentration of wheat in two growing seasons of 2012 and 2013. The obtained CV percentage of grain protein concentration under drought stress (16.35) was lower than that of non-stress conditions (20.42) (Table 5). These results indicate the higher stability of grain protein content of Azar-2 cultivar of wheat under drought stress environment. Giunta et al. [60] evaluated grain protein stability in old and modern durum wheat cultivars, grown under different cropping systems in terms of soil fertility, sowing date, sowing rate, and nitrogen rate, and reported that the greatest genotype and year interaction $(\mathrm{G} \times \mathrm{Y})$ was obtained by the more favorable years. They also reported that the interaction of rainfall, during post-anthesis, with nitrogen availability was the main cause of $\mathrm{G} \times \mathrm{Y}$ interaction for grain protein percentage [60].

Table 5. Combined analysis of variance of the main and interactive effects of nitrogen and potassium fertilizers on qualitative characteristics of Azar-2 cultivar of wheat under drought stress and non-stress environments.

\begin{tabular}{|c|c|c|c|c|c|c|c|c|c|c|c|}
\hline \multirow{4}{*}{ Source of Variation } & \multirow{4}{*}{$\mathrm{df}^{\mathrm{a}}$} & \multicolumn{10}{|c|}{ Mean Squares } \\
\hline & & \multicolumn{5}{|c|}{ Drought Stress } & \multicolumn{5}{|c|}{ Non-Stress } \\
\hline & & \multicolumn{2}{|c|}{ Flag Leaves } & \multicolumn{3}{|c|}{ Grain } & \multicolumn{2}{|c|}{ Flag Leaves } & \multicolumn{3}{|c|}{ Grain } \\
\hline & & $\mathbf{N}$ & $\mathbf{K}$ & $\mathbf{N}$ & $\mathbf{K}$ & Protein & $\mathbf{N}$ & $\mathbf{K}$ & $\mathbf{N}$ & $\mathbf{K}$ & Protein \\
\hline Year $(\mathrm{Y})$ & 1 & $0.013 \mathrm{~ns}$ & $4.263 * *$ & $4.438 * *$ & $0.001 \mathrm{~ns}$ & $144.158 * *$ & $3.323 * *$ & $0.672 * *$ & $3.046 * *$ & $0.015 \mathrm{~ns}$ & $105.169 * *$ \\
\hline Year $\times$ Block & 4 & $0.957^{* *}$ & $0.090 \mathrm{~ns}$ & $1.475 * *$ & $0.045 * *$ & $47.927 * *$ & $1.042 * *$ & $0.336^{* *}$ & 3.674 ** & $0.012 \mathrm{~ns}$ & $120.638 * *$ \\
\hline Nitrogen (N) & 3 & $0.068 \mathrm{~ns}$ & $0.058 \mathrm{~ns}$ & $0.093 \mathrm{~ns}$ & $0.003 \mathrm{~ns}$ & $3.073 \mathrm{~ns}$ & $0.436 \mathrm{~ns}$ & $0.280 *$ & $0.092 \mathrm{~ns}$ & $0.006 \mathrm{~ns}$ & $2.435 \mathrm{~ns}$ \\
\hline $\mathrm{Y} \times \mathrm{N}$ & 3 & $0.098 \mathrm{~ns}$ & $0.140 *$ & $0.029 \mathrm{~ns}$ & $0.012 \mathrm{~ns}$ & $0.932 \mathrm{~ns}$ & $0.303 \mathrm{~ns}$ & $0.064 \mathrm{~ns}$ & $0.187 \mathrm{~ns}$ & $0.008 \mathrm{~ns}$ & $7.067 \mathrm{~ns}$ \\
\hline Potassium (K) & 3 & $0.113 \mathrm{~ns}$ & $0.047 \mathrm{~ns}$ & $0.084 \mathrm{~ns}$ & $0.002 \mathrm{~ns}$ & $2.722 \mathrm{~ns}$ & $0.184 \mathrm{~ns}$ & $0.044 \mathrm{~ns}$ & $0.057 \mathrm{~ns}$ & $0.001 \mathrm{~ns}$ & $2.584 \mathrm{~ns}$ \\
\hline $\mathrm{Y} \times \mathrm{K}$ & 3 & $0.070 \mathrm{~ns}$ & $0.021 \mathrm{~ns}$ & $0.003 \mathrm{~ns}$ & $0.003 \mathrm{~ns}$ & $0.083 \mathrm{~ns}$ & $0.222 \mathrm{~ns}$ & $0.073 \mathrm{~ns}$ & $0.280 \mathrm{~ns}$ & $0.003 \mathrm{~ns}$ & $10.751 \mathrm{~ns}$ \\
\hline $\mathrm{N} \times \mathrm{K}$ & 9 & $0.131 \mathrm{~ns}$ & $0.039 \mathrm{~ns}$ & $0.271 * *$ & $0.006 \mathrm{~ns}$ & $8.820 * *$ & $0.271 \mathrm{~ns}$ & $0.070 \mathrm{~ns}$ & $0.126 \mathrm{~ns}$ & $0.003 \mathrm{~ns}$ & $3.992 \mathrm{~ns}$ \\
\hline $\mathrm{Y} \times \mathrm{N} \times \mathrm{K}$ & 9 & $0.199 \mathrm{~ns}$ & $0.082 \mathrm{~ns}$ & 0.206 * & $0.007 \mathrm{~ns}$ & $6.638 *$ & $0.151 \mathrm{~ns}$ & $0.050 \mathrm{~ns}$ & $0.205 \mathrm{~ns}$ & $0.004 \mathrm{~ns}$ & $7.533 \mathrm{~ns}$ \\
\hline Error & 60 & 0.196 & 0.044 & 0.099 & 0.005 & 3.199 & 0.208 & 0.091 & 0.197 & 0.006 & 6.405 \\
\hline CV (\%) & & 15.40 & 16.61 & 16.360 & 24.320 & 16.350 & 14.090 & 23.170 & 20.350 & 20.740 & 20.420 \\
\hline
\end{tabular}

The main effects of $\mathrm{N}$ and $\mathrm{K}$ fertilizers were not significant on investigated qualitative characteristics, except in non-stress condition that the main effect of $\mathrm{N}$ fertilizer on potassium content of flag leaves was significant at $5 \%$ probability level (Table 5). Flag leaves are an important source of $\mathrm{N}$ metabolites, including amino acids, which then transport them into the developing kernels [61]. Under drought stress conditions, the interactive effect of $\mathrm{N} \times \mathrm{K}$ fertilizers was significant on nitrogen and protein contents of wheat grain at a $1 \%$ probability level; however, this effect was not significant on all investigated qualitative characteristics under non-stress condition (Table 5). The interactive effect of year $\times \mathrm{N} \times \mathrm{K}$ was only significant on nitrogen and protein contents of wheat grains at a $5 \%$ probability level under drought stress conditions (Table 5). These results indicate the importance of applied fertilizers on qualitative characteristics of wheat grain under water deficiency condition. The use of different nutrients is one of the practical strategies to maintain wheat flour quality. Tao et al. [40] investigated the effect of sulfur fertilization on wheat grain production and wheat flour proteins and reported that grain and protein yields; grain weight; total protein, albumin, gliadin, glutenin, and globulin contents; and total starch were increased using sulfur fertilization. In terms of grain protein concentration stability, the lowest calculated CV was obtained from interaction of $\mathrm{N} 90 \times \mathrm{K} 60$ (7.77); however, the highest $\mathrm{CV}$ percentage was obtained from the sole application of $\mathrm{K}$ fertilizer $(\mathrm{N} 0 \times \mathrm{K} 30)$ (31.52) (Figure $1 \mathrm{~b}$ ). Therefore, the co-application of $\mathrm{N}$ and $\mathrm{K}$ fertilizers led to the higher grain protein content stability than the individually applied fertilizers (Figure 1b). Balanced nutrition-co-application of $\mathrm{N}, \mathrm{P}$, and $\mathrm{K}$, nutrients-may protect proteins against protein dilution as yields increase [42]. Water availability and nutrients supply both can affect the grain $\mathrm{N}$ concentration and grain protein content of wheat. Yan et al. [62] reported the 
different responses of the grain $\mathrm{N}$ concentration of winter wheat to the changing rates of fertilization and irrigation. Authors stated that the grain $\mathrm{N}$ concentration was firstly increased and then decreased with increasing rate of fertilization, whereas increasing irrigation rate first led to decrease and then increase of this trait.

Based on the means comparison analysis of the combined data of 2014-2015 and 2015-2016 growing seasons, using LSD test, the highest means of nitrogen and protein contents of wheat grains were obtained from interactive effects of $\mathrm{N} 60 \times \mathrm{K} 0$ treatment (Figure $3 a, b)$. The lowest means of these two qualitative characteristics were obtained from $\mathrm{N} 0 \times \mathrm{K} 0$ treatment (Figure $3 \mathrm{a}, \mathrm{b})$. These results indicate the superiority of $\mathrm{N}$ than $\mathrm{K}$ in wheat grain quality. In comparison with control treatment (N0K0), protein content of wheat grains increased by $2.90 \%$ with application of N90K0 (Figure $2 \mathrm{~b}$ ). However, in contrast to N0K0, protein content changes were $0.24 \%,-2.28 \%$, and $-0.44 \%$ with N90K30, N90K60, and N90K90 fertilizers, respectively (Figure $2 \mathrm{~b}$ ). The reduced protein content of wheat grains with increasing levels of $\mathrm{K}$ fertilizer, in a constant level of $\mathrm{N}$ fertilizer (N90), can be related to the disturbed nutritional balance of wheat under drought stress conditions.
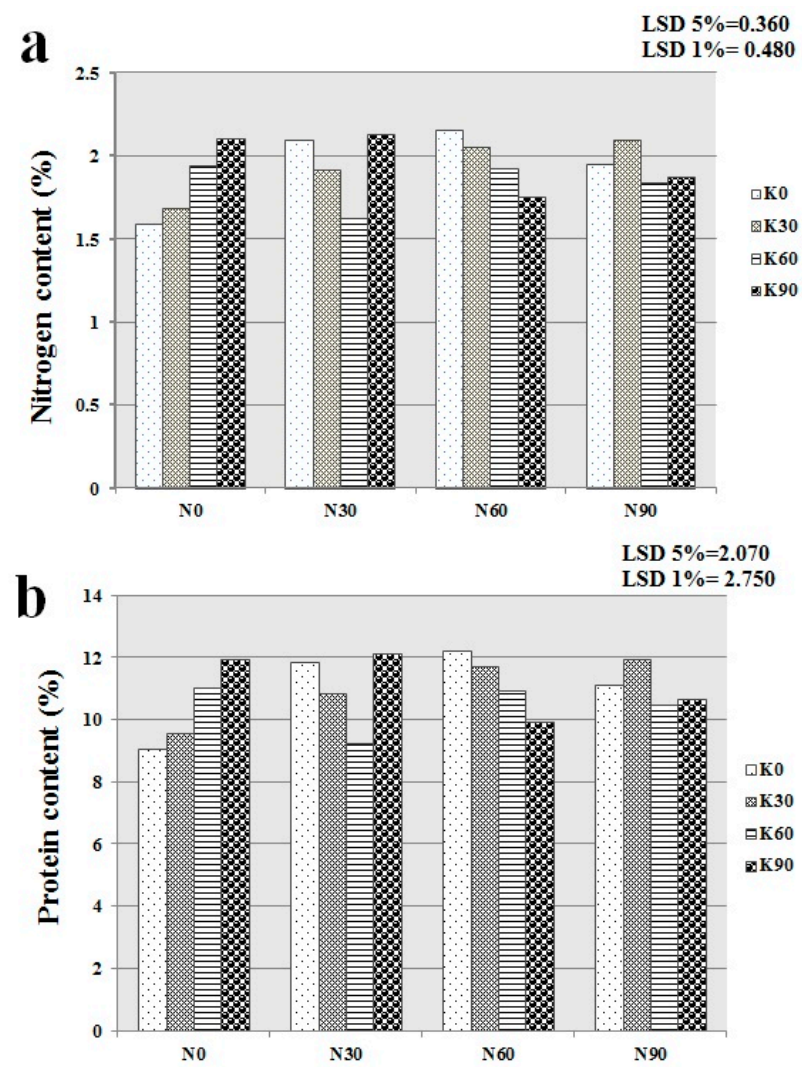

Figure 3. The means comparison analysis of the interactive effects of nitrogen and potassium fertilizers on qualitative characteristics of Azar-2 cultivar of wheat under drought stress condition using LSD test at $5 \%$ and $1 \%$ probability levels. (a) The interactive effects of nitrogen and potassium fertilizers on nitrogen content of grains. (b) The interactive effects of nitrogen and potassium fertilizers on protein content of grains.

The positive effect of nitrogen fertilization on nitrogen and protein content of wheat grain has been reported previously [63]. Evaluation of long-term (1966-2016) experimental data revealed that grain-nitrogen concentration of wheat increased linearly with increases in $\mathrm{N}$, whereas it reduced with increases in $\mathrm{P}$ and $\mathrm{K}$ rate [64]. Nitrogen regime has important role in the concentration of storage protein in wheat grains and bread-making quality [59]. Increasing grain protein concentration with increasing levels of $\mathrm{N}$ fertilizer has been reported in wheat [65]. Zhang et al. [66] reported that expression of glutamine synthetase genes (GS1 and GS2) in wheat cultivars were significantly increased with applied high 
levels of $\mathrm{N}$ fertilizer. They also reported that high nitrogen resulted in increased grain yield, grain protein content, and protein fraction. Grain protein concentration is an important factor that determines baking quality of wheat flour. The protein content of wheat grains is more than other important cereals—-such as maize (Zea mays), millet (Pennisetum glaucum), rice (Oryza sativa), and rye (Secale cereale)—which makes wheat flour valuable for the production of bread, pasta, and other bakery products [56]. Obtained grain protein concentration under drought stress condition (12.24\%) (Figure 3b) is suitable for bakery products, as recently it has been reported that baking volume of wheat varieties with a $1-2 \%$ lesser protein content than varieties with high raw protein content (13-16\%) was similar [56].

3.4. Main and Interactive Effects of $N$ and K Nutrients on Yield-Based Drought Tolerance Indices of Wheat

Estimated values of YP, YS, MP, GMP, TOL, SSI, STI, K1STI, and K2STI in Azar-2 cultivar of wheat under the interactive effects of $\mathrm{N}$ and $\mathrm{K}$ fertilizers are presented in Table 6. The highest YP and YS values were obtained from N90 × K90 and N90 × K60, respectively (Table 6). The highest MP, GMP, STI, K1STI, and K2STI drought tolerance indices were obtained from the interaction of $\mathrm{N} 90 \times \mathrm{K} 60$; whereas the lowest values of the mentioned DTI were obtained from N0 $\times$ K60 interactive effect (Table 6). The highest and lowest estimated TOL and SSI values were obtained from the N90 $\times$ K30 and N0 $\times$ K90 interactive effects, respectively (Table 6). The obtained results indicate the greater importance of $\mathrm{N}$ fertilizer than $\mathrm{K}$ fertilizer in drought tolerance of wheat. These results also showed the high interaction effects of investigated concentrations of $\mathrm{N}$ and $\mathrm{K}$ fertilizers on DTI of Azar-2 cultivar of wheat. Correlation coefficient of drought tolerance indices and grain yield is a suitable criterion for screening the best indices [67].

Table 6. Drought indexes in different rates of nitrogen and potassium fertilizers in rainfed wheat over two years.

\begin{tabular}{|c|c|c|c|c|c|c|c|c|c|c|}
\hline $\begin{array}{l}\text { Nitrogen } \\
\text { (kg/ha) }\end{array}$ & $\begin{array}{l}\text { Potassium } \\
\text { (kg/ha) }\end{array}$ & $\begin{array}{c}\text { Ys } \\
\text { (kg/ha) }\end{array}$ & $\begin{array}{c}\text { Yp } \\
\text { (kg/ha) }\end{array}$ & MP & GMP & TOL & SSI & STI & K2STI & K1STI \\
\hline \multirow{4}{*}{ N0 } & K0 & 1483 & 1881 & 1682 & 1670 & 398 & 0.86 & 0.48 & 0.31 & 0.29 \\
\hline & K30 & 1537 & 1853 & 1695 & 1688 & 317 & 0.70 & 0.49 & 0.35 & 0.28 \\
\hline & K60 & 1411 & 1924 & 1667 & 1648 & 512 & 1.08 & 0.47 & 0.28 & 0.29 \\
\hline & K90 & 1461 & 1700 & 1580 & 1576 & 238 & 0.57 & 0.43 & 0.27 & 0.21 \\
\hline \multirow{4}{*}{ N30 } & K0 & 1898 & 2356 & 2127 & 2114 & 458 & 0.79 & 0.77 & 0.83 & 0.72 \\
\hline & K30 & 1885 & 2254 & 2070 & 2061 & 369 & 0.67 & 0.73 & 0.78 & 0.63 \\
\hline & K60 & 1638 & 2230 & 1934 & 1911 & 592 & 1.08 & 0.63 & 0.50 & 0.53 \\
\hline & K90 & 1731 & 2278 & 2005 & 1986 & 547 & 0.98 & 0.68 & 0.61 & 0.59 \\
\hline \multirow{4}{*}{ N60 } & K0 & 1835 & 2731 & 2283 & 2238 & 896 & 1.34 & 0.86 & 0.87 & 1.08 \\
\hline & K30 & 2060 & 2646 & 2353 & 2335 & 585 & 0.90 & 0.94 & 1.19 & 1.10 \\
\hline & K60 & 1906 & 2514 & 2210 & 2189 & 609 & 0.99 & 0.83 & 0.89 & 0.88 \\
\hline & K90 & 1962 & 2737 & 2350 & 2317 & 775 & 1.15 & 0.93 & 1.06 & 1.17 \\
\hline \multirow{5}{*}{ N90 } & K0 & 2110 & 2748 & 2429 & 2408 & 638 & 0.95 & 1.00 & 1.33 & 1.27 \\
\hline & K30 & 1880 & 2880 & 2380 & 2327 & 1000 & 1.41 & 0.93 & 0.98 & 1.30 \\
\hline & K60 & 2142 & 2896 & 2519 & 2491 & 754 & 1.06 & 1.07 & 1.46 & 1.51 \\
\hline & K90 & 2129 & 2903 & 2516 & 2486 & 774 & 1.09 & 1.07 & 1.44 & 1.51 \\
\hline & Mean & 1817 & 2408 & 2112 & 2090 & 591 & 0.98 & 0.77 & 0.82 & 0.83 \\
\hline
\end{tabular}

Yp: grain yield under non-stress condition; Ys: grain yield under drought-stress condition; MP: mean productivity; GMP: geometric mean productivity; TOL: tolerance; SSI: stress susceptibility index; STI: stress tolerance index K1STI: modified stress tolerance index in non-stress condition; K2STI: modified stress tolerance index in drought stress condition.

The simple correlation of calculated yield-based drought tolerance indices with grain yield under the non-stressed (Yp) and moisture-stressed (Ys) conditions are shown in Table 7. K2STI showed the highest positive correlation with grain yield under drought stress 
condition $\left(\mathrm{r}=0.96^{* *}\right)$, following with GMP and STI indices $\left(\mathrm{r}=0.94^{* *}\right)$ (Table 7). K1STI, MP, GMP, and STI showed the highest positive correlation with grain yield under non-stress condition (Table 7). Nitrogen can improve drought tolerance of wheat through affecting physiological and biochemical processes such as accumulation of osmoprotectants and activity of antioxidant enzymes [26]. There is a positive correlation between water deficit stress and accumulation of reactive oxygen species (ROS) in cellular organelles $[1,68]$. Some cellular components, such as osmoprotectants and antioxidants, can stabilize cell membrane and proteins under stressful conditions through scavenging cellular ROS accumulation and keeping cell osmotic pressure [7,69]. In other hands, it has been reported that exogenous nitrogen supply led to higher osmoprotectants, antioxidant system, and lower relative membrane permeability in wheat plants [30]. Therefore, ROS detoxification and osmotic adjustment are the possible physiological mechanisms through which $\mathrm{N}$-fertilizer can alleviate damages of drought stress in wheat and other plants.

Table 7. Simple correlations of yield-based drought tolerance indices and grain yield of Azar-2 cultivar of wheat.

\begin{tabular}{ccccccccc}
\hline & Ys & Yp & MP & GMP & TOL & SSI & STI & K2STI \\
\hline Ys & 1 & & & & & & & \\
Yp & $0.85^{* *}$ & 1 & & & & & & \\
MP & $0.92^{* *}$ & $0.97^{* *}$ & 1 & & & & \\
GMP & $0.94^{* *}$ & $0.95^{* *}$ & $0.99^{* *}$ & 1 & & & \\
TOL & $0.56^{*}$ & $0.86^{* *}$ & $0.77^{* *}$ & $0.75^{* *}$ & 1 & & & \\
SSI & $0.23^{\text {ns }}$ & $0.63^{* *}$ & $0.48 \mathrm{~ns}$ & $0.45 \mathrm{~ns}$ & $0.90^{* *}$ & 1 & & \\
STI & $0.94^{* *}$ & $0.95^{* *}$ & $0.99^{* *}$ & $0.99^{* *}$ & $0.75^{* *}$ & $0.45 \mathrm{~ns}$ & 1 & \\
K2STI & $0.96^{* *}$ & $0.94^{* *}$ & $0.98^{* *}$ & $0.99^{* *}$ & $0.73^{* *}$ & $0.43 \mathrm{~ns}$ & $0.99^{* *}$ & 1 \\
K1STI & $0.89^{* *}$ & $0.99^{* *}$ & $0.98^{* *}$ & $0.97^{* *}$ & $0.83^{* *}$ & $0.57^{*}$ & $0.97^{* *}$ & $0.96^{* *}$ \\
\hline
\end{tabular}

Yp: grain yield under non-stress condition; Ys: grain yield under drought-stress condition; MP: mean productivity; GMP: geometric mean productivity; TOL: tolerance; SSI: stress susceptibility index; STI: stress tolerance index; K1STI: modified stress tolerance index in non-stress condition; K2STI: modified stress tolerance index in drought stress condition. ${ }^{* *}, *$ : Significant at $1 \%$ and $5 \%$ probability level, respectively. ns: not significant.

Estimated SSI values from the interaction of different rates of $\mathrm{N}$ fertilizer across applied rates of $\mathrm{K}$ fertilizer showed decreasing trend in interaction of lowest concentration of $\mathrm{N}$ (N30) with increased concentration of $\mathrm{K}$ (K0 to K30), and then it was increased with increasing levels of K (Figure 4a). Estimated STI values during two investigated growing seasons showed an increasing trend with increasing rates of $\mathrm{N}$ fertilizer across applied rates of $\mathrm{K}$ fertilizer (Figure $4 \mathrm{~b}$ ). The intersection point of STI trend curve was observed in $\mathrm{N} 60 \times \mathrm{K} 30$ and $\mathrm{N} 90 \times \mathrm{K} 30$ (Figure $4 \mathrm{~b}$ ). Therefore, there is no significant difference between these two interactive treatments in terms of grain yield under drought stress condition. However, the highest STI values were obtained by N90K60 and N90K90. K1STI was also had uniform trends with changing rates of $\mathrm{N}$ fertilizer across different rates of $\mathrm{K}$ fertilizer (Figure 4c). Unlike K1STI, K2STI showed variable trends, especially with N60 and N90 across different concentrations of $\mathrm{K}$ fertilizer (Figure $4 \mathrm{~d}$ ). The highest values of K1STI and K2STI were also obtained by interactive rates of N90K60 and N90K90 (Figure 4c,d). At all, it can be concluded that $\mathrm{N} 90 \mathrm{~K} 60$ and N90K90 were the best interactive rates of $\mathrm{N}$ and $\mathrm{K}$ fertilizers in terms of drought tolerance indices. However, N90K60 is the best, as the intersection point of SSI was also obtained in K60 (Figure 4a).

Drought stress indices are mainly applyied by researchers to find most tolerant genotypes among huge number of studied genotypes. However, in the present study, DTI were applied to find the best interaction(s) of $\mathrm{N}$ and $\mathrm{K}$ fertilizers for enhance drought tolerance of a rainfed cultivar, Azar-2, cultivar of wheat. Sedri et al. [3] used drought stress indices of MP, GMP, TOL, SSI, STI, K1STI, and K2STI to evaluate effect of different concentrations of $\mathrm{N}$ fertilizer on drought tolerance of rainfed wheat and reported that application of $60 \mathrm{~kg} / \mathrm{ha} \mathrm{N}$ fertilizer improved both grain yield and drought tolerance of wheat. Khan and Mohammad [70] used stress tolerance indices of TOL, MP, harmonic mean (HM), SI, GMP, 
STI, YI, YSI, low nitrogen tolerance index (LNTI), nitrogen stress index (NSI), nitrogen index (NI), stress susceptibility percentage index (SSPI), K1STI, K2STI, and relative nitrogen index $(\mathrm{RNI})$ to assess grain yield of wheat varieties under with $(\mathrm{N}+)$ and without nitrogen (N0) conditions. They reported that only NI had a positive correlation with grain yield under stress conditions [70].
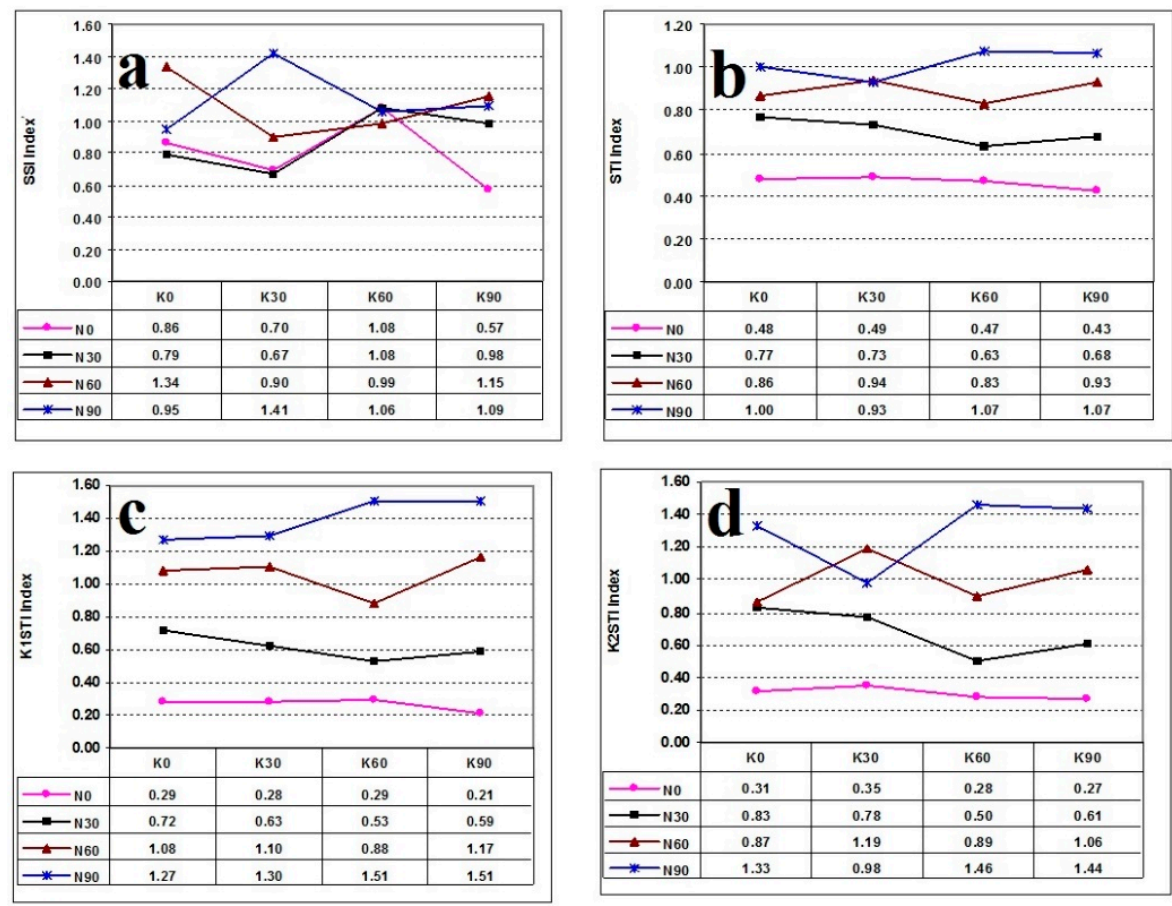

Figure 4. Trend of drought tolerance indices of Azar-2 cultivar of wheat under interactive effects of nitrogen and potassium fertilizers. (a) Trend of estimated SSI values under interactive effects of different concentrations of nitrogen and potassium fertilizers. (b) Trend of estimated STI values under interactive effects of different concentrations of nitrogen and potassium fertilizers. (c) Trend of estimated K1STI values under interactive effects of different concentrations of nitrogen and potassium fertilizers. (d) Trend of estimated K2STI values under interactive effects of different concentrations of nitrogen and potassium fertilizers.

Although yield-based DTI are most applied tools to identify tolerant genotypes in different crops, however, their discrimination efficiency depends on stress severity. Mohammadi [71] applied STI, GMP, MP, TOL, SSI, YSI, and YI drought tolerance indices to identify tolerant genotypes of durum wheat under mild, moderate, and severe levels of drought stress and reported that, under severe stress, discrimination among the genotypes was better than mild stress condition.

\section{Conclusions}

The exogenous supply of some nutrients, especially nitrogen, can improve grain yield, grain quality, and yield stability of wheat. In addition, these nutrients can alleviate drought stress-induced yield loss of wheat. The interactive effects of $\mathrm{N}$ and $\mathrm{K}$ fertilizers were not significant on grain yield trait, under both drought stress and non-stress environments; however, the main effect of $\mathrm{N}$ was significant on grain yield in both investigated environments. The interactive effects of $\mathrm{N}$ and $\mathrm{K}$ fertilizers, under drought stress conditions, significantly affected the grain protein content. In comparison with control treatment (N0K0), the highest increases of grain yield and grain protein content were obtained from the interactive rates of N90K60 and N90K0, respectively. The grain yield stability, based on calculated CV percentage of grain yield, of Azar-2 rainfed cultivar of wheat in drought stress condition was lower than non-stress condition. Calculated CV percentage of grain protein content under drought stress was lower than that obtained from non-stress con- 
dition. In terms of grain yield and grain protein content stability, the combined use of $\mathrm{N}$ and $\mathrm{K}$ fertilizers (interaction of $\mathrm{N} 90 \times \mathrm{K} 60$ ) was better than $\mathrm{N}$ and $\mathrm{K}$ fertilizers individually. The interaction of $\mathrm{N} 90 \times \mathrm{K} 60$ led to the highest estimated MP, GMP, STI, K1STI, and K2STI drought tolerance indices. K2STI, GMP, and STI had the highest positive correlation with grain yield of Azar-2 rainfed cultivar of wheat under drought stress condition.

The positive effect of $\mathrm{N}$ fertilizer on yield and drought tolerance of wheat was significant in the present study. However, using other components involved in chilling tolerance-such as brassinosteroids and hydrogen sulfide-along with $\mathrm{N}$ fertilizer could enhance drought-chilling tolerance of wheat and increase its productivity under environments similar to the environment of the present study (cool and dry).

The present study could be expanded to include other types of fertilizers (individually or combined) and other wheat genotypes in future experiments. Different toleranceenhancing components could be used along with conventional fertilizers to enhance biotic and abiotic stress tolerance of wheat genotypes. However, there are some limitations for both in-door and open filed assessments in this regard. Genotype $\times$ environment interaction is an important influencing factor that should be considered in stress tolerance assessment experiments. Many phenological, morphological, physiological, and biochemical characteristics must be assessed to find the best interaction(s) of applied stress tolerance-enhancers. This creates a multi-factorial condition, which is difficult to interpret. Advanced machine learning algorithms could be useful to make the right decisions in these situations.

Author Contributions: Conceptualization, M.H.S., E.R. and G.N.; Methodology, M.H.S. and G.N.; Software, M.H.S. and E.R.; Validation, M.H.S., E.R. and G.N.; Formal analysis, M.H.S. and G.N.; Investigation, M.H.S. and E.R.; Resources, M.H.S.; Data curation, M.H.S., E.R., and G.N.; Writingoriginal draft preparation, M.N. and G.N.; Writing-review and editing, G.N.; Visualization, M.N.; Supervision, M.H.S. and G.N.; Project administration, M.H.S. and E.R.; Funding acquisition, M.H.S. All authors have read and agreed to the published version of the manuscript.

Funding: This research (Grant Code: 3-052-182300-00-0000-84121) was funded by Dryland Agricultural Research Institute (DARI) of Iran.

Data Availability Statement: The datasets generated during and/or analyzed during the current study are available from the corresponding author on reasonable request.

Conflicts of Interest: The authors declare no conflict of interest.

\section{References}

1. Ma, D.; Sun, D.; Wang, C.; Ding, H.; Qin, H.; Hou, J.; Huang, X.; Xie, Y.; Guo, T. Physiological Responses and Yield of Wheat Plants in Zinc-Mediated Alleviation of Drought Stress. Front. Plant Sci. 2017, 8, 860. [CrossRef]

2. Niedbała, G.; Nowakowski, K.; Rudowicz-Nawrocka, J.; Piekutowska, M.; Weres, J.; Tomczak, R.J.; Tyksiński, T.; Pinto, A.Á. Multicriteria prediction and simulation of winter wheat yield using extended qualitative and quantitative data based on artificial neural networks. Appl. Sci. 2019, 9, 2773. [CrossRef]

3. Sedri, M.H.; Amini, A.; Golchin, A. Evaluation of Nitrogen Effects on Yield and Drought Tolerance of Rainfed Wheat using Drought Stress Indices. J. Crop Sci. Biotechnol. 2019, 22, 235-242. [CrossRef]

4. Wasaya, A.; Manzoor, S.; Yasir, T.A.; Sarwar, N.; Mubeen, K.; Ismail, I.A.; Raza, A.; Rehman, A.; Hossain, A.; EL Sabagh, A. Evaluation of Fourteen Bread Wheat (Triticum aestivum L.) Genotypes by Observing Gas Exchange Parameters, Relative Water and Chlorophyll Content, and Yield Attributes under Drought Stress. Sustainability 2021, 13, 4799. [CrossRef]

5. Bukhari, S.A.B.H.; Lalarukh, I.; Amjad, S.F.; Mansoora, N.; Naz, M.; Naeem, M.; Bukhari, S.A.; Shahbaz, M.; Ali, S.A.; Marfo, T.D.; et al. Drought Stress Alleviation by Potassium-Nitrate-Containing Chitosan/Montmorillonite Microparticles Confers Changes in Spinacia oleracea L. Sustainability 2021, 13, 9903. [CrossRef]

6. Farooq, M.; Wahid, A.; Kobayashi, N.; Fujita, D.; Basra, S.M.A. Plant Drought Stress: Effects, Mechanisms and Management. In Sustainable Agriculture; Springer: Dordrecht, The Netherlands, 2009; pp. 153-188.

7. Niazian, M.; Sadat-Noori, S.A.; Tohidfar, M.; Galuszka, P.; Mortazavian, S.M.M. Agrobacterium-mediated genetic transformation of ajowan (Trachyspermum ammi (L.) Sprague): An important industrial medicinal plant. Ind. Crops Prod. 2019, 132, 29-40. [CrossRef]

8. Arafa, S.A.; Attia, K.A.; Niedbała, G.; Piekutowska, M.; Alamery, S.; Abdelaal, K.; Alateeq, T.K.; Ali, M.A.M.; Elkelish, A.; Attallah, S.Y. Seed Priming Boost Adaptation in Pea Plants under Drought Stress. Plants 2021, 10, 2201. [CrossRef] 
9. Anwaar, H.A.; Perveen, R.; Mansha, M.Z.; Abid, M.; Sarwar, Z.M.; Aatif, H.M.; ud din Umar, U.; Sajid, M.; Aslam, H.M.U.; Alam, M.M.; et al. Assessment of grain yield indices in response to drought stress in wheat (Triticum aestivum L.). Saudi J. Biol. Sci. 2020, 27, 1818-1823. [CrossRef]

10. Noori, S.A.S. Assessment for salinity tolerance through intergeneric hybridisation: Triticum durum $\times$ Aegilops speltoides. Euphytica 2005, 146, 149-155. [CrossRef]

11. Rosielle, A.A.; Hamblin, J. Theoretical Aspects of Selection for Yield in Stress and Non-Stress Environment. Crop Sci. 1981, 21, 943-946. [CrossRef]

12. Fischer, R.; Maurer, R. Drought resistance in spring wheat cultivars. I. Grain yield responses. Aust. J. Agric. Res. 1978, 29, 897. [CrossRef]

13. Fernandez, G.C.J. Effective selection criteria for assessing stress tolerance. In Proceedings of the International Symposium on Adaptation of Vegetables and Other Food Crops in Temperature and Water Stress, Taibei, Taiwan, 13-16 August 1992; Kuo, C.G., Ed.; AVRDC Publication: Tainan, Taiwan, 1992; pp. 257-270.

14. Schneider, K.A.; Rosales-Serna, R.; Ibarra-Perez, F.; Cazares-Enriquez, B.; Acosta-Gallegos, J.A.; Ramirez-Vallejo, P.; Wassimi, N.; Kelly, J.D. Improving Common Bean Performance under Drought Stress. Crop Sci. 1997, 37, 43-50. [CrossRef]

15. Fischer, R.; Wood, J. Drought resistance in spring wheat cultivars. III.* Yield associations with morpho-physiological traits. Aust. J. Agric. Res. 1979, 30, 1001. [CrossRef]

16. Gavuzzi, P.; Rizza, F.; Palumbo, M.; Campanile, R.G.; Ricciardi, G.L.; Borghi, B. Evaluation of field and laboratory predictors of drought and heat tolerance in winter cereals. Can. J. Plant Sci. 1997, 77, 523-531. [CrossRef]

17. Bouslama, M.; Schapaugh, W.T. Stress Tolerance in Soybeans. I. Evaluation of Three Screening Techniques for Heat and Drought Tolerance. Crop Sci. 1984, 24, 933-937. [CrossRef]

18. Mitra, J. Genetics and genetic improvement of drought resistance in crop plants. Curr. Sci. 2001, 80, 758-763.

19. REZA RAMAZANI, S.H.; KALANTARI, R.T. Evaluating the effect of sowing date and drought stress on morphological and functional characteristics of three genotypes of winter oilseed rape (Brassica napus L.). Acta Agric. Slov. 2019, 113, 63. [CrossRef]

20. Ferede, B.; Mekbib, F.; Assefa, K.; Chanyalew, S.; Abraha, E.; Tadele, Z. Evaluation of Drought Tolerance in Tef [Eragrostis Tef (Zucc.) Trotter] Genotypes Using Drought Tolerance Indices. J. Crop Sci. Biotechnol. 2020, 23, 107-115. [CrossRef]

21. Singh, C.; Kumar, V.; Prasad, I.; Patil, V.R.; Rajkumar, B.K. Response of upland cotton (G.hirsutum L.) genotypes to drought stress using drought tolerance indices. J. Crop Sci. Biotechnol. 2016, 19, 53-59. [CrossRef]

22. Boussakouran, A.; Sakar, E.H.; El Yamani, M.; Rharrabti, Y. Morphological Traits Associated with Drought Stress Tolerance in Six Moroccan Durum Wheat Varieties Released Between 1984 and 2007. J. Crop Sci. Biotechnol. 2019, 22, 345-353. [CrossRef]

23. Mickky, B.; Aldesuquy, H.; Elnajar, M. Uni- and Multi-Variate Assessment of Drought Response Yield Indices in 10 Wheat Cultivars. J. Crop Sci. Biotechnol. 2019, 22, 21-29. [CrossRef]

24. Elkelish, A.; El-Mogy, M.M.; Niedbała, G.; Piekutowska, M.; Atia, M.A.M.; Hamada, M.M.A.; Shahin, M.; Mukherjee, S.; El-Yazied, A.A.; Shebl, M.; et al. Roles of Exogenous $\alpha$-Lipoic Acid and Cysteine in Mitigation of Drought Stress and Restoration of Grain Quality in Wheat. Plants 2021, 10, 2318. [CrossRef]

25. El-Saadony, F.M.A.; Mazrou, Y.S.A.; Khalaf, A.E.A.; El-Sherif, A.M.A.; Osman, H.S.; Hafez, E.M.; Eid, M.A.M. Utilization Efficiency of Growth Regulators in Wheat under Drought Stress and Sandy Soil Conditions. Agronomy 2021, 11, 1760. [CrossRef]

26. Shabbir, R.N.; Waraich, E.A.; Ali, H.; Nawaz, F.; Ashraf, M.Y.; Ahmad, R.; Awan, M.I.; Ahmad, S.; Irfan, M.; Hussain, S.; et al. Supplemental exogenous NPK application alters biochemical processes to improve yield and drought tolerance in wheat (Triticum aestivum L.). Environ. Sci. Pollut. Res. 2016, 23, 2651-2662. [CrossRef] [PubMed]

27. Macholdt, J.; Honermeier, B. Stability analysis for grain yield of winter wheat in a long-term field experiment. Arch. Agron. Soil Sci. 2019, 65, 686-699. [CrossRef]

28. Abid, M.; Tian, Z.; Ata-Ul-Karim, S.T.; Cui, Y.; Liu, Y.; Zahoor, R.; Jiang, D.; Dai, T. Nitrogen Nutrition Improves the Potential of Wheat (Triticum aestivum L.) to Alleviate the Effects of Drought Stress during Vegetative Growth Periods. Front. Plant Sci. 2016, 7. [CrossRef] [PubMed]

29. Wang, X.; Wang, L.; Shangguan, Z. Leaf Gas Exchange and Fluorescence of Two Winter Wheat Varieties in Response to Drought Stress and Nitrogen Supply. PLoS ONE 2016, 11, e0165733. [CrossRef] [PubMed]

30. Agami, R.A.; Alamri, S.A.M.; Abd El-Mageed, T.A.; Abousekken, M.S.M.; Hashem, M. Role of exogenous nitrogen supply in alleviating the deficit irrigation stress in wheat plants. Agric. Water Manag. 2018, 210, 261-270. [CrossRef]

31. Wani, J.A.; Malik, M.A.; Dar, M.A.; Akhter, F.; Raina, S.K. Impact of method of application and concentration of potassium on yield of wheat. J. Environ. Biol. 2014, 35, 623-626.

32. Lv, X.; Li, T.; Wen, X.; Liao, Y.; Liu, Y. Effect of potassium foliage application post-anthesis on grain filling of wheat under drought stress. Field Crop. Res. 2017, 206, 95-105. [CrossRef]

33. Damon, P.M.; Ma, Q.F.; Rengel, Z. Wheat genotypes differ in potassium accumulation and osmotic adjustment under drought stress. Crop Pasture Sci. 2011, 62, 550. [CrossRef]

34. Jeer, M.; Yele, Y.; Sharma, K.C.; Prakash, N.B. Exogenous Application of Different Silicon Sources and Potassium Reduces Pink Stem Borer Damage and Improves Photosynthesis, Yield and Related Parameters in Wheat. Silicon 2021, 13, 901-910. [CrossRef]

35. Hu, W.; Jiao, Z.; Wu, F.; Liu, Y.; Dong, M.; Ma, X.; Fan, T.; An, L.; Feng, H. Long-term effects of fertilizer on soil enzymatic activity of wheat field soil in Loess Plateau, China. Ecotoxicology 2014, 23, 2069-2080. [CrossRef] 
36. Raza, M.A.; Saleem, M.; Shah, G.; Khan, I.; Raza, A. Exogenous application of glycinebetaine and potassium for improving water relations and grain yield of wheat under drought. J. Soil Sci. Plant Nutr. 2014, 14, 348-364. [CrossRef]

37. Kant, S.; Kafkafi, U.; Pasricha, N.; Bansal, S. Potassium and abiotic stresses in plants. Potassium Sustain. Crop Prod. Gurgaon 2002, $233,251$.

38. Luo, L.; Wang, Z.; Huang, M.; Hui, X.; Wang, S.; Zhao, Y.; He, H.; Zhang, X.; Diao, C.; Cao, H.; et al. Plastic film mulch increased winter wheat grain yield but reduced its protein content in dryland of northwest China. Field Crop. Res. 2018, 218, 69-77. [CrossRef]

39. Seleiman, M.F.; Al-Suhaibani, N.; Ali, N.; Akmal, M.; Alotaibi, M.; Refay, Y.; Dindaroglu, T.; Abdul-Wajid, H.H.; Battaglia, M.L. Drought Stress Impacts on Plants and Different Approaches to Alleviate Its Adverse Effects. Plants 2021, 10, 259. [CrossRef]

40. Tao, Z.; Chang, X.; Wang, D.; Wang, Y.; Ma, S.; Yang, Y.; Zhao, G. Effects of sulfur fertilization and short-term high temperature on wheat grain production and wheat flour proteins. Crop J. 2018, 6, 413-425. [CrossRef]

41. Zahra, N.; Wahid, A.; Hafeez, M.B.; Ullah, A.; Siddique, K.H.M.; Farooq, M. Grain development in wheat under combined heat and drought stress: Plant responses and management. Environ. Exp. Bot. 2021, 188, 104517. [CrossRef]

42. Duncan, E.G.; O'Sullivan, C.A.; Roper, M.M.; Biggs, J.S.; Peoples, M.B. Influence of co-application of nitrogen with phosphorus, potassium and sulphur on the apparent efficiency of nitrogen fertiliser use, grain yield and protein content of wheat: Review. Field Crop. Res. 2018, 226, 56-65. [CrossRef]

43. Hesami, A.; Amini, A. Changes in irrigated land and agricultural water use in the Lake Urmia basin. Lake Reserv. Manag. 2016, 32, 288-296. [CrossRef]

44. Yoshida, S.; Forno, D.A.; Cock, J.H. Laboratory Manual for Physiological Studies of Rice; CAB International: Los Banos, Philippines, 1971.

45. Han, X.; Hu, C.; Chen, Y.; Qiao, Y.; Liu, D.; Fan, J.; Li, S.; Zhang, Z. Crop yield stability and sustainability in a rice-wheat cropping system based on 34-year field experiment. Eur. J. Agron. 2020, 113, 125965. [CrossRef]

46. Farshadfar, E.; Sutka, J. Screening drought tolerance criteria in maize. Acta Agron. Hungarica 2002, 50, 411-416. [CrossRef]

47. HAO, M.-D.; FAN, J.; WANG, Q.-J.; DANG, T.-H.; GUO, S.-L.; WANG, J.-J. Wheat Grain Yield and Yield Stability in a Long-Term Fertilization Experiment on the Loess Plateau. Pedosphere 2007, 17, 257-264. [CrossRef]

48. Müller, C.; Elliott, J.; Pugh, T.A.M.; Ruane, A.C.; Ciais, P.; Balkovic, J.; Deryng, D.; Folberth, C.; Izaurralde, R.C.; Jones, C.D.; et al Global patterns of crop yield stability under additional nutrient and water inputs. PLoS ONE 2018, 13, e0198748. [CrossRef]

49. Miranzadeh, H.; Emam, Y.; Pilesj\&ouml, P.; Seyyedi, H. Water Use Efficiency of Four Dryland Wheat Cultivars under Different Levels of Nitrogen Fertilization. J. Agric. Sci. Technol. 2011, 13, 843-854.

50. Fateh, H.; Toube, A.; Gholipuri, A.Q. The feasibility of reducing yield gap by improving crop management. Ukr. J. Ecol. 2019, 9 , 21-30. [CrossRef]

51. Liu, Z.; Sun, K.; Liu, W.; Gao, T.; Li, G.; Han, H.; Li, Z.; Ning, T. Responses of soil carbon, nitrogen, and wheat and maize productivity to 10 years of decreased nitrogen fertilizer under contrasting tillage systems. Soil Tillage Res. 2020, 196, 104444. [CrossRef]

52. Macholdt, J.; Piepho, H.-P.; Honermeier, B. Mineral NPK and manure fertilisation affecting the yield stability of winter wheat: Results from a long-term field experiment. Eur. J. Agron. 2019, 102, 14-22. [CrossRef]

53. Chen, H.; Deng, A.; Zhang, W.; Li, W.; Qiao, Y.; Yang, T.; Zheng, C.; Cao, C.; Chen, F. Long-term inorganic plus organic fertilization increases yield and yield stability of winter wheat. Crop J. 2018, 6, 589-599. [CrossRef]

54. Zhang, P.; Ma, G.; Wang, C.; Lu, H.; Li, S.; Xie, Y.; Ma, D.; Zhu, Y.; Guo, T. Effect of irrigation and nitrogen application on grain amino acid composition and protein quality in winter wheat. PLoS ONE 2017, 12, e0178494. [CrossRef]

55. Seddaiu, G.; Iocola, I.; Farina, R.; Orsini, R.; Iezzi, G.; Roggero, P.P. Long term effects of tillage practices and N fertilization in rainfed Mediterranean cropping systems: Durum wheat, sunflower and maize grain yield. Eur. J. Agron. 2016, 77, 166-178. [CrossRef]

56. Zörb, C.; Ludewig, U.; Hawkesford, M.J. Perspective on Wheat Yield and Quality with Reduced Nitrogen Supply. Trends Plant Sci. 2018, 23, 1029-1037. [CrossRef]

57. Pettigrew, W.T. Potassium influences on yield and quality production for maize, wheat, soybean and cotton. Physiol. Plant. 2008, 133, 670-681. [CrossRef]

58. Fang, P.; Yan, M.; Chi, C.; Wang, M.; Zhou, Y.; Zhou, J.; Shi, K.; Xia, X.; Foyer, C.H.; Yu, J. Brassinosteroids Act as a Positive Regulator of Photoprotection in Response to Chilling Stress. Plant Physiol. 2019, 180, 2061-2076. [CrossRef] [PubMed]

59. Vazquez, D.; Berger, A.; Prieto-Linde, M.L.; Johansson, E. Can nitrogen fertilization be used to modulate yield, protein content and bread-making quality in Uruguayan wheat? J. Cereal Sci. 2019, 85, 153-161. [CrossRef]

60. Giunta, F.; Pruneddu, G.; Motzo, R. Grain yield and grain protein of old and modern durum wheat cultivars grown under different cropping systems. Field Crops Res. 2019, 230, 107-120. [CrossRef]

61. Barneix, A.; Guitman, M.R. Leaf regulation of the nitrogen concentration in the grain of wheat plants. J. Exp. Bot. 1993, 44, 1607-1612. [CrossRef]

62. Yan, S.; Wu, Y.; Fan, J.; Zhang, F.; Zheng, J.; Qiang, S.; Guo, J.; Xiang, Y.; Zou, H.; Wu, L. Dynamic change and accumulation of grain macronutrient (N, P and K) concentrations in winter wheat under different drip fertigation regimes. Field Crop. Res. 2020, 250, 107767. [CrossRef]

63. Vrignon-Brenas, S.; Celette, F.; Amossé, C.; David, C. Effect of spring fertilization on ecosystem services of organic wheat and clover relay intercrops. Eur. J. Agron. 2016, 73, 73-82. [CrossRef] 
64. Lollato, R.P.; Figueiredo, B.M.; Dhillon, J.S.; Arnall, D.B.; Raun, W.R. Wheat grain yield and grain-nitrogen relationships as affected by N, P, and K fertilization: A synthesis of long-term experiments. Field Crop. Res. 2019, 236, 42-57. [CrossRef]

65. Xue, C.; auf'm Erley, G.S.; Rossmann, A.; Schuster, R.; Koehler, P.; Mühling, K.-H. Split Nitrogen Application Improves Wheat Baking Quality by Influencing Protein Composition Rather Than Concentration. Front. Plant Sci. 2016, 7. [CrossRef]

66. Zhang, M.; Ma, D.; Ma, G.; Wang, C.; Xie, X.; Kang, G. Responses of glutamine synthetase activity and gene expression to nitrogen levels in winter wheat cultivars with different grain protein content. J. Cereal Sci. 2017, 74, 187-193. [CrossRef]

67. Naghavi, M.; Pour-Aboughadareh, A.; Marouf, K. Evaluation of Drought Tolerance Indices for Screening Some of Corn (Zea mays L.) Cultivars under Environmental Conditions. Not. Sci. Biol. 2013, 5, 388-393. [CrossRef]

68. Batra, N.G.; Sharma, V.; Kumari, N. Drought-induced changes in chlorophyll fluorescence, photosynthetic pigments, and thylakoid membrane proteins of Vigna radiata. J. Plant Interact. 2014, 9, 712-721. [CrossRef]

69. Chen, H.; Hao, H.; Han, C.; Wang, H.; Wang, Q.; Chen, M.; Juan, J.; Feng, Z.; Zhang, J. Exogenous l-ascorbic acid regulates the antioxidant system to increase the regeneration of damaged mycelia and induce the development of fruiting bodies in Hypsizygus marmoreus. Fungal Biol. 2020, 124, 551-561. [CrossRef] [PubMed]

70. Khan, F.U.; Mohammad, F. Application of stress selection indices for assessment of nitrogen tolerance in wheat (Triticum aestivum L.). J. Anim. Plant Sci. 2016, 26, 201-210.

71. Mohammadi, R. Efficiency of yield-based drought tolerance indices to identify tolerant genotypes in durum wheat. Euphytica 2016, 211, 71-89. [CrossRef] 